\title{
Doświadczanie dorosłości osoby Głuchej w ujęciu jednostkowym i społecznym
}

\author{
Adulthood experience of the Deaf person in an individual \\ and social take
}

\begin{abstract}
Streszczenie. W artykule podjęto próbę ukazania specyfiki procesu kształtowania się tożsamości osób Głuchych*, a także wchodzenia w okres dorosłości. Sytuacja osób Głuchych w Polsce ulega zmianie, coraz więcej z nich podejmuje studia, zwiększa się dla tej grupy dostępność do rynku pracy, osoby Głuche mogą liczyć na wsparcie tłumaczy języka migowego. Te udogodnienia wpływają na poczucie niezależności i autonomii w podejmowaniu zadań związanych z okresem dorosłości. Jednak czy w rozumieniu subiektywnym, jednostkowym możemy mówić o pełnym realizowaniu przez te osoby zadań rozwojowych wynikających z okresu dorosłości? Jaką rolę w kontekście wchodzenia w dorosłość odgrywa tożsamość społeczno-kulturowa u osób Głuchych?
\end{abstract}

Słowa kluczowe: dorosłość; dorosły; g/Głuchy; tożsamość społeczno-kulturowa Głuchych

Summary. The following article attempts to show the specifics of shaping the identity of Deaf people, as well as their entering into adulthood. The situation of Deaf people in Poland is changing, more and more people are taking up university courses, and access to the labour market for this group of people is increasing. They can also count on the support of sign language interpreters. Certainly, these amenities affect the sense of independence and autonomy when comes to the tasks arising from adulthood. However, can we talk about the full implementation of developmental tasks arising from adulthood in the subjective,

* Zgodnie z pisownią upowszechnioną w literaturze polskiej słowo „Głuchy” pisane wielką literą oznacza głuchotę w aspekcie społeczno-kulturowym jako czynnik tożsamościowy. Natomiast słowo "głuchy" zapisywane małą literą odnosi się do wszystkich głuchych, niezależnie od stopnia uszkodzenia słuchu, wyznacznikiem w tym rozumieniu jest sam fakt uszkodzenia słuchu. Zapis g/Głuchy oznacza, że prezentowane treści dotyczą zarówno jednego, jak i drugiego aspektu głuchoty. 
individual understanding? What role does social and cultural identity play in the entering of Deaf people into adulthood?

Keywords: adulthood; adult; d/Deaf; social and cultural identity of the Deaf

\section{Wstęp}

Dorosłość to okres, który pomimo przypisanych mu ogólnych zadań rozwojowych doświadczany jest w indywidualny sposób. W tym czasie przed każdym dorosłym stoją określone zadania rozwojowe. Najbardziej charakterystycznym zadaniem wynikającym $\mathrm{z}$ wejścia w okres dorosłości jest przyjęcie pełnej odpowiedzialności za własne wybory. Jest to proces niezwykle trudny, dokonuje się zgodnie z koncepcją zadań życiowych, która łączy określone formy aktywności z wiekiem. Pierwszymi zadaniami rozwojowymi okresu dorosłości według psychologów (Brzezińska, 2005; Harwas-Napierała, Trempała, 2007; Oleś, 2015) są: wejście w relacje rodzinne, partnerskie (wybór partnera, decyzja o wspólnym życiu, wychowanie dzieci, opieka nad rodzicami), wejście na ścieżkę rozwoju zawodowego (przyjęcie roli pracownika, współpracownika, kierowanie ludźmi itp.), wejście w relacje towarzyskie (dbanie o przyjaciół, budowanie sieci wsparcia - dla siebie i swoich bliskich itp.) oraz wejście w relacje obywatelskie (angażowanie się w działania na rzecz społeczności lokalnej, udział w wyborach itp.). Najpopularniejsza definicja człowieka dorosłego $w$ andragogice, sformułowana przez Włodzimierza Szewczuka (1961), zakłada, że dorosły człowiek jest odpowiedzialny za siebie, jest podmiotem działalności produkcyjnej, sam decyduje o swoim planie życiowym, sam musi uporać się z trudnościami jego realizacji, odpowiada wobec społeczeństwa za swoją działalność. Mocne strony dorosłości to odpowiedzialność, nieżelazność, autonomia. W przypadku osoby Głuchej odpowiedzialność może być ograniczona i zależna od środowiska, w którym ta osoba funkcjonuje. Jaka jest dorosłość osoby z uszkodzonym słuchem? Czy utrata słuchu jest determinantem w procesie osiągania dorosłości?

\section{Dorosłość w kontekście tożsamości społecznej i kulturowej Głuchych}

Dorosły w świetle teorii psychologii humanistycznej jest capable being, czyli zdolny do stawania się - bez określenia do czego; jest zdolny do samo- 
dzielnego myślenia i odpowiedzialności do wyboru (Artaud, za: Czerniawska 1996). Dorosłość zawiera dwa wymiary znaczeń: obiektywny i subiektywny. Pierwszy z nich odnosi się do normy społecznej i do fazy życia ludzkiego określonej ramami chronologicznymi. Drugi wyraża się w przeżyciach jednostki, która pod wpływem wydarzeń osobistych lub społecznych postrzega siebie jako osobę dorosłą, już niemłodą, starzejącą się i odtąd stara się uzewnętrznić normy przypisane tej fazie wieku i realizować określony jej wzór. Głuchy jako osoba dorosła funkcjonuje zarówno w wymiarze biosocjokulturowym, wpisanym w swoją kulturę, grupę społeczną i niepełnosprawność, jak i w wymiarze subiektywnym, jednostkowym. W obu osoba Głucha musi przekroczyć progi dorosłości. Próg odnoszący się do normy społecznej czasami musi przekroczyć szybciej, co wynika z jej sytuacji społecznej którą determinuje głuchota. Głuchy musi wcześniej stać się dorosły, samodzielny $\mathrm{w}$ rozumieniu radzenia sobie $\mathrm{w}$ relacjach społecznych, ponoszenia odpowiedzialności za siebie.

W drugim przypadku doświadcza swojej dorosłości i postrzega siebie jako osobę dorosłą, ale głównie pod wpływem przeżyć jednostkowych, na które często oddziałują kontakty społeczne. Na te kontakty składają się relacje występują zarówno w obrębie środowiska niesłyszących, jak i słyszących. A są to dwa różne światy, dlatego postrzeganie siebie może być dwoiste. W środowisku niesłyszących Głuchy może być postrzegany inaczej niż wśród słyszących. Jawi się jako niezależny, samodzielny, zdolny do odpowiedzialności, odgrywania ról rodzinnych, zawodowych, społecznych. Przez osoby słyszące postrzegany jest natomiast jako osoba potrzebująca wsparcia, tłumacza języka migowego przy załatwianiu spraw urzędowych, niezdolna do podejmowania wszystkich ról zawodowych, mająca ograniczenia uniemożliwiające jej wykonywanie niektórych zawodów, niezdolna do pełnienia kierowniczych stanowisk, do odpowiedzialności za innych itp. Taki rozdźwięk w odczuwaniu własnej dorosłości może wpłynąć na postrzeganie siebie jako samodzielnej i niezależnej osoby dorosłej. W jakim stopniu zatem osoba Głucha czuje się dorosła? Czy jej dorosłość jest uwarunkowana tym, z którym środowiskiem się komunikuje, kontaktuje, zważywszy, że dorosłość wyraża się w przeżyciach jednostki budujących poczucie własnej tożsamości, szczególnie w relacjach z innymi? W przypadku osób Głuchych mogą to być relacje z dwoma odmiennymi światami. Czy w tych relacjach dorosły Głuchy może mieć poczucie pewności siebie, poczucie odpowiedzialności za przynależność do grupy społecznej? A jeśli tak, to do której z tych grup? Czy może odczuwać autorytet i władzę? Wobec kogo? Czy tylko względem swojego środowiska? 
Wymiar społeczny takiego konfliktu może wynikać z pewnego paradoksu polegającego na tym, że osoba Głucha nie szuka wzorca swojej dorosłości, a jedynie uwewnętrznia wzory dorosłości swoich rodziców, innych Głuchych. Dopiero od niedawna można zaobserwować proces emancypowania się tej grupy osób spod wpływów/władzy „Innych”. Tymi „Innymi” zazwyczaj są osoby słyszące (Podgórska-Jachnik 2013). Badaczka epistemologii głuchych Goedele DeClerck (2012) wskazuje na trzystopniowy model emancypacji Głuchych. Stopień pierwszy opisuje stan społeczności Głuchych znajdujących się pod wpływem oralizmu, podporządkowanych i wycofanych z życia społecznego. Drugi stopień emancypacji oznacza upolitycznienie kwestii tożsamości Głuchych za sprawą legitymizacji języka migowego, która dokonała się dzięki badaniom językoznawczym. Wreszcie trzeci stopień emancypacji dotyczy stanu, w którym młode Głuche osoby traktują bycie głuchym jako jeden $\mathrm{z}$ aspektów różnorodności w pluralistycznym społeczeństwie, $z$ łatwością komunikują się transnarodowo, a także w niektórych przypadkach rozwijają swoją transnarodową głuchą tożsamość.

Uwewnętrznianie swojej dorosłości może być więc zależne od stopnia identyfikacji ze środowiskiem słyszących lub niesłyszących. Dorosły niesłyszący, aby sprostać oczekiwaniom zarówno jednego, jak i drugiego środowiska, jest skazany na ciągłe uczenie się bycia dorosłym, wchodzenie w nowe role. Wkraczanie w dorosłość może odbywać się, jak pisze Anna Pawełczyńska (1984), dwutorowo. Po pierwsze, przebiega ono w wymiarze analityczno-logicznego poznawania, poszukiwania wiedzy ogólnej, naukowej, stopniowego przyswajania wiedzy na swój temat i swojej niepełnosprawności. Po drugie - w wymiarze intuicyjno-uczuciowym, który służy rozumieniu świata. Człowiek poprzez intuicję stara się poznawać siebie - w perspektywie całościowego oglądu świata, w oparciu o swoje miejsce w świecie.

Podjęcie zadań okresu dorosłości, a przede wszystkim ich konsekwentne oraz satysfakcjonujące realizowanie, możliwe jest jednak dzięki pewnym trendom rozwojowym charakterystycznym dla okresu dorosłości (White 1975, za: Brzezińska 2005, s. 427). W nich upatruje się źródeł zasobów i potencjałów, takich jak:

- stabilizacja własnej tożsamości;

- nawiązanie głębszych związków interpersonalnych, co wiąże się z uwolnieniem się od samego siebie, a zarazem wyczuleniem na potrzeby innych;

- pogłębienie dziedzin aktywności, jak praca, nauka, zainteresowania;

- wyraźniejsze dostrzeganie problemów moralnych i etycznych;

- wzrost znaczenia troski nie tylko o najbliższych, ale również o wszystkich potrzebujących i cierpiących (White 1975, za: Brzezińska 2005, s. 427). 
Pisząc o osobach niesłyszących/głuchych, powinniśmy być świadomi niejednoznaczności stosowanych w Polsce określeń, w szczególności musimy być wyczuleni na stosowanie wielkiej litery w słowie „Głuchy”, gdyż znaczenia określenia „osoba głucha” (małą literą) i „osoba Głucha” (wielką literą) mają trochę inny sens. Szersze znaczenie zawiera się w określeniu „osoba głucha”, zapisywanym małą literą, którego synonimem jest „niesłyszący/a”. Obejmuje ono osoby głuche, tj. posiadające fizyczne, wrodzone lub nabyte deficyty biologiczne uniemożliwiające lub w znacznym stopniu utrudniające słyszenie. Przez osoby Głuche, pisane wielką literą, rozumie się osoby słyszące lub niesłyszące, identyfikujące się z subkulturą/społecznością Głuchych. Należy natomiast unikać sformułowania „głuchoniemy”, gdyż jest ono odbierane jako pejoratywne. Uważa się, że nazwa ta podwójnie stygmatyzuje niesłyszącego - jako człowieka bez języka, niesłyszącego i niemówiącego. Głusi tymczasem komunikują się bez problemu, mają własny język wizualno-przestrzenny, którym jest język migowy (por. Białas 2007).

Postrzeganie głuchoty jako przywileju stało się elementem spajającym grupę, a tym samym jednym z czynników tożsamościowych, obok jedności przekonań, historii, edukacji, języka czy wytworów kulturowych.

Proces stabilizacji własnej tożsamości jest chyba najtrudniejszym zadaniem czasu dorosłości w przypadku osób Głuchych. Już na poziomie jednostki może być problemem. Wymaga bowiem uformowania spójnej i stabilnej struktury „ja”, stanowiącej efekt odpowiedzi na wymagania środowiska, oczekiwania innych ludzi oraz własne aspiracje i marzenia w taki sposób, że jednostka ujawnia otwartość wobec tego, co ją otacza, wchodzi w bliskie relacje z ludźmi, nie obawiając się utraty własnej autonomii, indywidualności i odrębności. Jednocześnie dla podjęcia zadań okresu dorosłości konieczne jest osiągnięcie tożsamości społecznej, związanej ze strukturą „my”. Dzięki niej możliwe jest z kolei satysfakcjonujące odgrywanie ról wiążących się z pozostawaniem w bliskości z drugim człowiekiem, bez obawy o utratę własnej autonomii, poczucia swobody działania oraz z podejmowaniem razem z nim czy też na jego rzecz współpracy (Brzezińska, 2005, s. 427).

W przypadku osób Głuchych proces nabywania tożsamości i jej stabilizacja jest procesem złożonym i wieloaspektowym obejmującym pokonywanie rozmaitych konfliktów. Jest swoistym kompromisem pomiędzy chęcią samorealizacji a normami i regułami, które narzuca społeczeństwo; w przypadku osób niesłyszących będą to normy narzucane przez świat osób słyszących i niesłyszących. Bywa on jeszcze bardziej złożony i trudny, gdyż wymaga zmierzenia się z dodatkowymi trudnościami, czego często doświadczają ludzie należący do grup społecznych będących - pod jakimiś względami - 
mniejszościami. W przypadku młodych ludzi o nieukształtowanej jeszcze w pełni tożsamości może to utrudniać odpowiedzi na najważniejsze na tym etapie życia pytania: Kim jestem? Gdzie jest moje miejsce w społeczeństwie? (Tomaszewski, Kotowska, Krzysztofiak 2017, s. 111).

Bogdan Szczepankowski (1999, s. 167) na temat tożsamości pisze:

Doświadczenia własne, symulowane np. przez zatkanie sobie uszu palcami, prowadzą do zrozumienia głuchoty wyłącznie jako utraty słuchu, a w konsekwencji do postrzegania tego w kategoriach nieszczęścia. Nie wystarczy jednak odizolować się od dźwięków, by doznawać takich wrażeń, jak osoby niesłyszące. Postrzeganie osób niesłyszących, w tym przede wszystkim niesłyszących kulturowo jako takich, które słuch straciły i żyją w „świecie ciszy”, jest głęboko nieprawdziwe. W rzeczywistości bowiem, tak jak dla osoby słyszącej normalną rzeczą jest słyszeć i mówić, a tragedią wydaje się perspektywa utraty słuchu, tak dla osoby głuchej od urodzenia "nie słyszeć” jest zjawiskiem naturalnym. W konsekwencji prowadzi do nieco innego postrzegania świata, a ponadto do funkcjonowania w komunikowaniu się i tożsamości takiej osoby w nieco inny sposób, niż czynią to osoby słyszące, co często budzi niechęć, niepokój i kontrowersje.

Przekonania te mogą wynikać z niewiedzy, na co wskazuje Bartnikowska (2010b, s. 86), zaznaczając, iż „[z]decydowana większość dzieci głuchych rodzi się [...] rodzicom słyszącym, natomiast większość ludzi niesłyszących ma słyszące potomstwo". Mogą być również podyktowane nieznajomością kulturowego potencjału Głuchych oraz wąskiego rozumienia kategorii niepełnosprawności.

Identyfikacja tożsamościowa ze społecznością Głuchych jest dodatkowo wzmacniana nadawaniem imion/nazwisk-znaków. Głusi, wchodząc w społeczność, zyskują znak, który jest ich osobistym określeniem, przynależy do nich, a w społeczności może być istotniejszy niż nadane przez rodziców imię i odziedziczone po nich nazwisko. Jak zauważa Grzesiak, przy spotkaniu Głuchych padają dwa pytania: Jak się nazywasz? Jak ciebie migają? Pierwsza odpowiedź jest zwykle przeliterowana z użyciem daktylografii, drugą stanowi przekazanie znaku ideograficznego przypisanego do danego człowieka (por. Grzesiak 2003, s. 511-561; Bartnikowska 2010a). Człowiek niesłyszący, wchodząc w społeczność Głuchych, uzyskuje pewien dodatkowy, charakterystyczny element tożsamości, ściśle związany z funkcjonowaniem tej mniejszości.

Czynnikiem sprzyjającym rozwojowi osobowości i tożsamości dorosłej osoby Głuchej jest praca. Stymuluje ona jej aktywność, zwiększa poczucie 
własnej wartości. Może także służyć zaspokojeniu potrzeby kontaktów społecznych. Według Bernadety Szczupał i Grażyny Dryżałowskiej (2004) obok funkcji dochodowej równie ważna staje się możliwość samorealizacji jednostki. Problemy zawodowe, jakie napotykają osoby niepełnosprawne, dotyczą wyboru zawodu lub jego zmiany wskutek nabycia niepełnosprawności, przygotowania się do pracy zawodowej i jej uzyskania czy zatrudnienia, adaptacji zawodowej i utrzymania się w zatrudnieniu. Jednym z problemów jest też rozbieżność pomiędzy posiadanymi kwalifikacjami a wymaganiami na otwartym rynku pracy. Na niekorzyść niepełnosprawnych przemawia fakt, że osoby te kształcono m.in. w zawodach, które obecnie zanikają, takich jak kowal czy szewc.

W przypadku osób Głuchych poczucie własnej tożsamości, jak również tożsamości wspólnotowej, społecznej, wiąże się z pojęciem tożsamości społeczno-kulturowej Głuchych. Charakterystyczne dla tego rodzaju tożsamości jest względnie trwałe identyfikowanie się nie tylko $z$ innymi członkami danej grupy społecznej, ale przede wszystkim z określonym układem kulturowym, a zwłaszcza zespołem idei, poglądów i przekonań dzielonych przez członków danej grupy. Ponadto taki układ mogą też tworzyć typowe dla danej kultury zwyczaje i zachowania, wierzenia, reprezentowany przez nią system aksjologiczny i normatywny, a także wszelkiego rodzaju artefakty danej kultury, takie jak utwory, historie, anegdoty, humor, powiedzenia czy żarty (Monghan, Senghas 2002, za: Tomaszewski, Kotowska, Krzysztofiak 2017). Warto zauważyć, że człowiek na przestrzeni życia zazwyczaj przynależy lub znajduje się pod wpływem więcej niż jednej grupy społecznej, systemu kultury. W przypadku osób Głuchych jest to świat osób słyszących i niesłyszących. Tożsamość społeczna bądź kulturowa w takim wypadku stanowi więc pochodną nakładania się różnych wpływów, którym podlega jednostka. Istotny wydaje się zatem stopień podobieństwa tychże wpływów. Jeżeli są one ze sobą zbieżne, elementy danych kultur nakładają się na siebie, wtedy wzajemnie się wzmacniają, a identyfikacja danej osoby z każdą z kultur jest pełniejsza. Jeśli natomiast elementy kultur wzajemnie się wykluczają, mamy do czynienia z dysonansem kulturowym, w wyniku którego u danej osoby może wytworzyć się niespójna tożsamość. Na pojawienie się tego rodzaju tożsamości narażone są osoby głuche lub niedosłyszące, które urodziły się i wychowały w środowiskach słyszących. To ryzyko szczególnie wzrasta w momencie zetknięcia się z kulturą Głuchych, kiedy to, bardzo często, pod wpływem poznania nowej kultury, nowego języka osoby te przedefiniowują swoją tożsamość i dotychczasową identyfikację kulturową (Tomaszewski, Kotowska, Krzysztofiak 2017, s. 114-115). Budowanie tożsamości Głu- 
chych zależy od modelu głuchoty, którą przyjmie jednostka, czy będzie to model społeczno-kulturowy, czy medyczny.

Niesłyszący, podobnie jak inne grupy, funkcjonują w zróżnicowanej przestrzeni społecznej, w której pewne cechy indywidualne, takie jak niepełnosprawność, wyznaczają określone miejsce. Odczytując pojęcia przypisane do osób z wadą słuchu, można rozpatrywać je w kontekście oceny stopnia niepełnosprawności (osoby odznaczające się najwyższym stopniem niepełnosprawności potrzebują największego wsparcia - dość często uzyskują jednak najniższe wykształcenie).

W rozważaniach na temat osób niesłyszących specjaliści zajmujący się zagadnieniami związanymi z osobami z uszkodzonym zmysłem słuchu zgodnie podkreślają występowanie znaczących różnic w tej populacji, co z kolei wpływa na stosowaną terminologię (Szczepankowski 1999; Korzon 2003; Csányi 2004; Podgórska-Jachnik 2013; Tomaszewski 2015b). Taka różnorodność wynika m.in. z odmiennych kryteriów kwalifikacyjnych, jak również różnych celów. Brak jednolitego i precyzyjnego rozróżnienia pojęć powoduje np. problemy w rozumieniu, kogo uważamy za osobę z uszkodzonym narządem słuchu. Aby podjąć próbę zinterpretowania modelu głuchoty, należy dokonać chociażby częściowej egzemplifikacji przyjętych pojęć. Trudności wynikają m.in. z tego, że różne dziedziny nauki posługują się odmienną terminologią, co należy uwzględnić, łącząc obszary o różnym stopniu oddziaływań przyczyniające się do wyodrębnienia pojęcia. Zróżnicowanie współczesnego nazewnictwa prezentują następujące podejścia:

1. W przepisach prawa Ministerstwa Edukacji Narodowej znajdziemy zapis o uczniach niepełnosprawnych mających trudności w uczeniu się i/lub komunikowaniu się, w tym niesłyszących, słabosłyszących*.

2. W orzecznictwie stosuje się ustalenia terminologiczne zalecone przez Międzynarodowe Biuro Audiofonologii (Szczepankowski 1999). Bogdan Szczepankowski przeprowadza szeroką analizę stosowanych definicji osób głuchych, niesłyszących, niedosłyszących i słabosłyszących. Proponuje przyjęcie definicji: osoba z uszkodzonym słuchem w stopniu lekkim, umiarkowanym, znacznym lub głębokim jest to osoba, której uszkodzenie słuchu, określone audiogramem progowym i przeliczone według tabeli Międzynarodowego Biura Audiofonologii (BIAP), przekracza 20 dB i kwalifikuje ją do jednego ze stopni uszkodzeń.

* Ministerstwo Edukacji Narodowej, https://men.gov.pl/niezbednik [dostęp: 20.02.2016]. 
3. W pracach specjalistycznych w dziedzinie medycyny występują terminy „upośledzenie słuchu” i „zaburzenie słuchu” (Skarżyński, Mueller-Malesińska, Wojnarowska 2002).

4. W surdopedagogice różnice dotyczą samego terminu, istoty rozumienia pojęcia głuchoty, jak również traktowania jej w odmienny sposób (Plutecka 2006). Dostrzega się m.in. związki z funkcjonowaniem społeczno-emocjonalnym, samooceną, jakością życia i tożsamością osoby głuchej, dzieci i młodzieży głuchej (słabosłyszącej), uczęszczających do różnych placówek edukacyjnych (Kobosko 2014).

5. Uwzględniając funkcjonowanie językowe, w sferze percepcji i recepcji mowy zaleca się określanie osób z uszkodzeniami słuchu jako: funkcjonalnie słyszące, niedosłyszące, słabosłyszące oraz funkcjonalnie niesłyszące (głuche) (Krakowiak 2003). Należy zaznaczyć, że wśród wszystkich osób z uszkodzeniami słuchu można wyróżnić co najmniej 107 grup. Każda z nich wymaga indywidualnego podejścia w rehabilitacji i edukacji (Krakowiak 2006).

6. W logopedii kryterium określania osoby z uszkodzonym słuchem stanowi preferowany sposób porozumiewania się oraz ogólny poziom rozwoju psychofizycznego (Gunia 2006).

7. Równie istotny jest relatywizm pojęcia głuchoty oraz jego związek z warunkami socjoekonomicznymi danego kraju. Tam, gdzie mamy do czynienia z wczesnym diagnozowaniem, dobrym przystosowaniem aparatów słuchowych, odpowiednim wychowaniem i kształceniem, termin ten może nie obejmować osób, które w innych krajach są uznawane za głuche.

8. Pomiędzy dwoma światami trudno określić, kto jest głuchym; osoby z uszkodzonym słuchem, które nie są w stanie spełnić wymogów ani społeczności głuchych, ani słyszących (Bartnikowska 2010b).

9. Związane $z$ wiedzą teoretyczną na temat sytuacji społecznej osób głuchych i wyrażaniem jej poprzez prezentowanie odmienności społeczności Głuchych i dążeniem do ukazania wyjątkowości osób głuchych (Podgórska-Jachnik 2013).

10. W środowisku Głuchych występują podziały i klasyfikacje np. na mniej głuchych i bardziej głuchych. Dostrzegany jest również nowy typ człowieka niesłyszącego, tzw. idealnego głuchego (Podgórska-Jachnik 2007). Zatem osoby $z$ wadą słuchu to zróżnicowana grupa społeczna dość często dzielona na: głuchych, niesłyszących, słabosłyszących.

11. Zachodzące zmiany, takie jak zastosowanie aparatów słuchowych, spowodowały, że wiele osób z nich korzystających, które jeszcze niedawno 
nazwalibyśmy niesłyszącymi, obecnie można określić w znacznym stopniu słyszącymi. Dla osób z uszkodzeniem słuchu w stopniu lekkim, które dobrze i samodzielnie funkcjonują w społeczeństwie, nie ma konieczności tworzenia odrębnego pojęcia (Krakowiak 2003). Można nazywać je osobami lekko niedosłyszącymi (Szczepankowski 2002).

\section{Dorosłość osób z uszkodzonym słuchem}

Patrząc na dorosłych Głuchych i ich codzienne funkcjonowanie, można przyjąć tezę, że głuchota sama w sobie nie stanowi czynnika ryzyka dla prawidłowego i satysfakcjonującego procesu wkraczania w dorosłość czy rozwoju procesów i mechanizmów adaptacyjnych. Może ona jednak tworzyć szczególny kontekst dla pewnych specyficznych zdarzeń życiowych, istotnych w procesie przejścia. Na rozwój procesu adaptacji, który z kolei implikuje właściwy poziom odporności psychicznej i kompetencje osób Głuchych wkraczających w dorosłość, wpływa interakcja zachodząca pomiędzy zmiennymi indywidualnymi i środowiskowymi (Masten, Obradovic, 2006; Young, Green, Rogers, 2008; Meyer, Kashubeck-West 2011, za: Kossewska 2017). Na gruncie polskim niewiele jest badań podejmujących problem wchodzenia w dorosłość osób z uszkodzonym słuchem. Więcej uwagi poświęca się w literaturze studentom niesłyszącym, problemom młodzieży, kulturze i tożsamości Głuchych Głuchych.

Badania z zakresu wchodzenia w dorosłość Głuchych przytacza Joanna Kossewska. Z badań amerykańskich (Valentine, Skelton 2007; Zand, Pierce 2013, za: Kossewska 2017) dotyczących tego zagadnienia wynika, że występuje pewne opóźnienie w zakresie podejmowania trwałych zobowiązań przy równoczesnym przedłużeniu fazy związanej z poznawaniem siebie i zbieraniem osobistych doświadczeń. Na podstawie badań wywnioskowano również, że możliwość korzystania z różnego rodzaju wsparcia powoduje u Głuchych bierność i ogranicza ich samodzielność, a także wzmacnia szok związany z przejściem z bezpiecznego środowiska szkolnego do dorosłego, rywalizującego świata, zdominowanego przez słyszącą większość. Inne badania, przeprowadzone przez Debrę Zand i Katherinę Pierce (2013, za: Kossewska 2017), skupiły się na analizie wypowiedzi 44 Głuchych absolwentów college'u lub studiów wyższych w wieku od 18 do 30 lat, dotyczących ważności i znaczenia doświadczanych zdarzeń życiowych. Z badań wynikało, że osoby młodsze częściej ujawniały doświadczenia typowe dla wcześniejszej fazy rozwojowej charakteryzujące się uniezależnianiem od rodziców, dosko- 
naleniem kompetencji, nawiązywaniem nowych, choć nie zawsze trwałych relacji społecznych. Natomiast starsza grupa podejmowała już trwałe zobowiązania wobec osób bliskich i kwestii zawodowych. Na wyniki badań miała wpływ również identyfikacja z kulturą Głuchych. Badani deklarowali, iż najważniejsze zdarzenia życiowe, stanowiące istotę dorosłości, związane są z ich udziałem w wydarzeniach dotyczących osób Głuchych, kontaktami z Głuchymi, posługiwaniem się językiem migowym. Takie zdarzenia mogą zapewnić Głuchym wchodzącym w dorosłość możliwości współobecności i współdziałania z osobami, z którymi łączą ich więzy tożsamości kulturowej. Wspólna silnie odczuwana tożsamość kulturowa może pomóc w radzeniu sobie z wyzwaniami otoczenia, jakie może napotkać członek mniejszości językowej. Identyfikacja z kulturą Głuchych jest również przejawem niezależności w świecie dorosłych (Luckner, Stewart 2003; Lukomski 2011, za: Kossewska 2017, s. 162-163).

Wstępne badania polskiej grupy głuchych/Głuchych w kontekście wyłaniającej się dorosłości zostały przeprowadzone przez Joannę Kossewską i Michała Gacka (2014, za: Kossewska 2017) z wykorzystaniem skali subiektywnej dorosłości (SSD) opracowanej przez Krzysztofa Piotrowskiego i Annę Brzezińską. Wyniki uzyskane przez osoby Głuche studiujące na polskich uczelniach ( $\mathrm{N}=40$, w wieku 20-25 lat) ujawniły, że subiektywne poczucie dorosłości pozostaje bez związku z głuchotą, wobec czego uprawnione jest przypuszczenie, że osoby Głuche doświadczają typowych dla okresu wyłaniającej się dorosłości zdarzeń normatywnych. Grupy (głuchych i słyszących) dobrane parami pod względem płci, wieku i kierunku kształcenia prezentowały bardzo zbliżony poziom poszczególnych wymiarów i aspektów subiektywnej dorosłości. Badania Kossewskiej i Gacka pokazują, że obie grupy badanych w podobny sposób oceniały swoje poczucie samodzielności, którego głównym elementem jest poczucie niezależności i autonomii. Tak więc poczucie samodzielności - czyli stopień przekonania o pełnej odpowiedzialności za własne działania, a także o umiejętności utrzymania samodzielności finansowej i samodzielnego rozwiązywania osobistych problemów, samodzielności w zakresie podejmowania decyzji dotyczących spraw wartych zaangażowania, samodzielnej realizacji własnych postanowień wydaje się niezależne od głuchoty. Zarówno poczucie emocjonalnego uniezależnienia się od rodziców, jak i samodzielności w działaniu i podejmowaniu osobistych decyzji, a także intymna relacja w bliskich związkach oraz poczucie dorosłości zostały ocenione przez uczestników w jednakowy sposób niezależnie od ubytku słuchu. Wyniki badań przeprowadzonych przez Joannę Kossewską i Michała Gacka (2014), choć uzyskane w bardzo nie- 
licznej grupie osób Głuchych, mogą prowadzić do konkluzji, iż głuchota nie stanowi czynnika ryzyka dla wyłaniającej się dorosłości, a osoby w analogicznym wieku metrykalnym i sytuacji społeczno-kulturowej w sposób podobny dokonują ewaluacji własnych doświadczeń rozwojowych. Należy jednak zwrócić uwagę, że badania dotyczą studentów, którzy chętnie uwalniają się spod kontroli rodzicielskiej, chcą samodzielnie, bez udziału rodziców podejmować decyzje o sobie samych, badają swoje potencjalne możliwości, podejmują próby stworzenia nowych związków, nawiązania przyjaźni i relacji miłosnych. Okres studiowania najczęściej wiąże się z czasowym i stopniowym opuszczaniem domu rodzinnego, a jednocześnie z możliwością bezpiecznego powrotu do niego w celu otrzymania różnego rodzaju wsparcia. Zmiany społeczne i rozwojowe wzmagają więc u osób głuchych/Głuchych, podobnie jak u słyszących, działania, które łączą się głównie z dalszym uzyskiwaniem wykształcenia oraz z pierwszymi doświadczeniami zawodowymi. Stosunkowo najniżej badana grupa Głuchych oceniała swoją dojrzałość społeczną, rozumianą jako gotowość utrzymania niezależności finansowej oraz budowania trwałego związku małżeńskiego, przy czym nie wykazuje pod tym względem różnic w stosunku do słyszących rówieśników. Brak istotnych różnic pomiędzy Głuchymi i słyszącymi może świadczyć o właściwie zrealizowanym procesie socjalizacji i integracji społecznej, któremu podlegała badana grupa w trakcie wcześniejszych etapów rozwoju w systemie edukacji sprzyjającym zaspokojeniu potrzeb rozwojowych (zob. Kossewska 2017, s. 164-167).

\section{Subiektywne doświadczanie dorosłości w narracji osoby Głuchej}

Jednym ze sposobów poznania procesu formowania tożsamości jest narracja, która opiera się na wywiadach swobodnych bądź częściowo ustrukturalizowanych. Narzędzie to daje możliwość wyrażenia swoich subiektywnych sądów. W trakcie opowiadania własnej historii kształtuje się bowiem tożsamość narratora. Egzemplifikacją podjętego tematu niech będą wypowiedzi dorosłej osoby, głuchej od urodzenia. Badany jest w wieku około 40 lat, pochodzi z rodziny kulturowo Głuchej:

Głuchota w mojej rodzinie nie była jakimś problemem czy zaskoczeniem. Co prawda mama przeżywała i chciała jednak, żeby dzieci słyszały, gdy urodziła się siostra i też wykryto u niej niedosłuch, mama przyjęła to z bólem. 
Pierwsze 3 lata przebywałem w domu pod opieką rodziców. Od 3. roku życia zacząłem uczęszczać do przedszkola, razem z dziećmi słyszącymi. Jednakże od początku izolowałem się od otoczenia, od początku nie zdawałem sobie sprawy z tego, że nie słyszę. Dla mnie taka sytuacja była naturalna, dopiero w przedszkolu zauważyłem, że coś jest nie tak. Inne dzieci dały mi to odczuć, gdyż naśmiewały się z tego, jak mówię. Pobyt w przedszkolu wspominam tak, że siedziałem i patrzyłem na poruszające się usta, ale nic z tego nie rozumiałem*.

Przedszkole i relacje z rówieśnikami na podwórku badany wspomina jako przykre, w zasadzie nie podejmował wspólnych zabaw z dziećmi słyszącymi, ciągle się izolował od rówieśników. Kontakty rówieśnicze zaczął kształtować dopiero wówczas, gdy poszedł do zerówki w szkole podstawowej dla dzieci niesłyszących. „Dopiero tam odżyłem i czułem, że mam kolegów, którzy byli tacy sami jak ja. Mogłem się z nimi bawić bez żadnego skrępowania”.

Rodzice mojego respondenta bardzo zabiegali, żeby uczył się mówić, chodził na zajęcia logopedyczne, zapisywali go na różne turnusy rehabilitacyjne, do logopedy. Zależało im, żeby uczył się mówić. Dla niego był to czas zbędny, niepotrzebny i zmarnowany - zabrany z dzieciństwa. Z perspektywy czasu, jako osoba dorosła, rozumie troskę i postępowanie rodziców:

$\mathrm{Z}$ perspektywy lat wiem, że rodzice chcieli dla mnie dobrze, $Z$ własnego doświadczenia wiedzieli, że osoba głucha i niemówiąca ma w życiu ciężko i ludzie nie traktują takich osób zbyt poważnie. Na podstawie własnych doświadczeń chcieli mnie uchronić przed tym. Istotę zajęć logopedycznych doceniłem tak naprawdę dopiero w szkole średniej. W tamtym okresie zacząłem intensywnie ćwiczyć, a gdy poznałem moją przyszłą żonę, moja chęć mówienia znacznie się zwiększyła. Niestety to już było trochę za późno.

W szkole badany radził sobie bardzo dobrze, był dobrym uczniem, zaangażowanym, uzdolnionym matematycznie, wyjeżdżał na olimpiady z matematyki dla dzieci niesłyszących, starał się osiągać dobre wyniki. Jako jeden z nielicznych, ponieważ w tamtym czasie odsetek uczniów szkół dla niesłyszących podejmujących naukę w liceum ogólnokształcącym był nieznaczny, dostał się do liceum w Warszawie. Po maturze podjął studia na pedagogice, chociaż marzeniem respondenta była matematyka, jednak w tamtych latach był to nieosiągalny kierunek studiów dla osoby Głuchej. Na studiach poznał swoją żonę, która jest osobą niedosłyszącą, posługującą się mową werbalną.

\footnotetext{
Cytowane wypowiedzi pochodzą z wywiadu przeprowadzonego przez autorkę, który jest w jej posiadaniu.
} 
Wszedł w rolę męża, ojca. I jak sam twierdzi, dopiero wtedy poczuł się bardziej samodzielny. „Teraz, jak mam rodzinę, wiele decyzji podejmuję razem z żoną, uwzględniając dobro całej rodziny. Wsparcie mam w żonie, pomaga mi w wielu sprawach, choćby takich jak zadzwonienie do kogoś".

W trakcie studiów respondent realizował praktyki w szkole, którą ukończył. Pomogło mu to potem w podjęciu zatrudnienia w ośrodku dla dzieci niesłyszących, którego był absolwentem. „Pierwszy dzień pracy nie był dla mnie zbyt nowy, ponieważ uczęszczałem na praktyki tam, gdzie pracuję, a później dwa lata przychodziłem na wolontariat, aż w końcu mnie zatrudniono. W pracy jestem samodzielny i sam podejmuję decyzje".

W pracy z dziećmi niesłyszącymi badany bardzo dobrze się odnajduje, zna to środowisko, rozumie problemy tych osób: „Myślę, że jestem sumiennym pracownikiem, ale niestety gorzej oceniany[m] przez kolegów. Oczywiście nie wszystkich, ale czasem widzę, że patrzą na mnie przez pryzmat ucznia głuchego, tzn. osoby, która jest niedouczona, lub uważają, że bariera słuchu jest przeszkodą w pracy". By móc realizować swoje marzenia związane z matematyką, gdy tylko pojawiły się możliwości zatrudniania tłumaczy języka migowego na innych kierunkach studiów poza pedagogiką, ukończył studia podyplomowe $\mathrm{z}$ matematyki. Nie wpłynęło to jednak na zmianę zatrudnienia, nadal jest wychowawcą w internacie, nie mogąc uzyskać wymarzonego stanowiska. Tę sytuację postrzega jako dyskryminującą go jako osobę głuchą. „Zważając na moje wykształcenie, od lat nie mam możliwości robienia tego, co chciałbym. Uważam, że moje doświadczenie życiowe jako osoby głuchej jest atutem w pracy z dziećmi głuchymi. Moja biegła znajomość języka migowego nie stwarza żadnych barier w komunikacji z uczniami".

Nieodzownym elementem dorosłości są relacje $z$ innymi. W przypadku mojego respondenta są one ograniczone barierą językową. Badany przebywa głównie w środowisku osób niesłyszących lub znających język migowy. W kontaktach $\mathrm{z}$ innymi wspomaga go żona:

Tak i tym pośrednikiem jest moja żona. Często mi pomaga w zawiłych sprawach urzędowych i sprawach, w których wymagana jest droga telefoniczna. Sprawami dzieci związanymi ze szkołą też raczej zajmuje się żona (zebrania itp.). W szczególności jak chcę coś załatwić i czuję tą niechęć drugiej osoby do współpracy, a wystarczy tylko wyciągnąć kartkę i długopis i komunikować się za pomocą pisma, co niestety nie zawsze jest dobrze odbierane przez osoby słyszące, i też irytują mnie rzeczy, gdzie nie ma możliwości załatwienia czegoś inną drogą, tylko telefonicznie, wtedy czuję duży dyskomfort, np. często banki oferują usługi tylko telefonicznie, ale w wielu innych życiowych sytua- 
cjach, że jakby była mi potrzebna natychmiastowa pomoc medyczna, tobym jej nie uzyskał (telefonicznie); często barierę, a wręcz frustrację odczuwam podczas oglądania telewizji. Brak napisów w ciekawych programach informacyjnych, a także filmach.

Swoją dorosłość badany postrzega w sposób dwoisty. Funkcjonuje w świecie osób Głuchych kulturowo, który jest mu bliski i bardzo dobrze znany, i w świecie osób słyszących - środowisku pracy, środowisku lokalnym, sąsiedzkim. I tutaj nie czuje się w pełni autonomiczny, samodzielny, odpowiedzialny za najbliższych. Skazany jest na pośrednictwo żony, tłumacza języka migowego, stara się posługiwać słowem pisanym: „Są sytuacje, które wprowadzają mnie w zakłopotanie, np. nie mogę uczestniczyć w ważnych wydarzeniach moich córek (słyszących); w wywiadówkach, mam poczucie, że nie jestem samodzielny".

Można powiedzieć, że dorosłość osoby Głuchej jest trudna, zwłaszcza jeżeli funkcjonuje ona w dwóch światach: osób słyszących i osób kulturowo Głuchych. Badany umie formułować odpowiedzi na pytania dotyczące siebie jako osoby, jako członka społeczeństwa, jako osoby odpowiedzialnej za siebie i innych. Jest przygotowany do wykonywania wybranego zawodu, potrafi podnosić swoje kwalifikacje zawodowe. Umie dokonywać wyboru wartości moralnych, filozoficznych, politycznych i swojego miejsca w świecie. Jest zdolny do obiektywnej oceny siebie i innych. Jednak w zakresie realizacji zadań rozwojowych okresu dorosłości doświadcza trudności - nie może ich wszystkich przeżywać ze względu na ubytek słuchu. Zdobywa doświadczenie wynikające z uczestnictwa w różnych sytuacjach, ze styczności społecznych, z wewnętrznych przeżyć i własnego postępowania. Doświadczenia życiowe doprowadzają do ukształtowania się poczucia tożsamości człowieka dorosłego i samooceny własnego rozwoju. I jest ono zdeterminowane przez utratę słuchu.

\section{Podsumowanie}

Dorośli Głusi, o których mowa, świadomie w języku fonicznym lub migowym rozwijają fałszywe self, co oznacza, że w większości „przybierają” tożsamość osoby „jak gdyby słyszącej”, „słyszącej” czy „głuchej”. U podstaw tego procesu leżą trudności w doświadczaniu własnej głuchoty i dostępie do emocji. Głuchota, obarczona negatywnymi emocjami i konfliktem, została przez nich i ich słyszących rodziców zaprzeczona. Zachowując zazwy- 
czaj tożsamość fałszywą, ludzie głusi nie mogą stać się „głuchymi na swój własny sposób".

Można sądzić, że środowisko społeczne, jakie tworzą ludzie niesłyszący w różnych sferach życia (edukacja, kultura, turystyka, sport itp.), stanowi ważne źródło pozytywnych doświadczeń osoby Głuchej. Należy mieć jednak na względzie, że przynależność do społeczności osób głuchych (czy Głuchych), słyszących lub zarówno Głuchych, jak i słyszących, wyrażająca się niejednokrotnie deklarowanym wyborem „tożsamości społecznej głuchych” czy „tożsamości społecznej słyszących”, czy też „dwukulturowości”, nie oznacza, iż osoba należąca do tej społeczności również pozytywnie doświadcza siebie wraz z własną głuchotą, a co więcej, czy, jak dodałby Carl Rogers, „czerpie cichą radość z bycia sobą”.

\section{Bibliografia}

Bartnikowska U. (2010a), Głuchota - mniejszość językowa, kulturowa, pogranicze... czyli społeczny kontekst badania zjawisk zwiq̨zanych z uszkodzeniem słuchu, „Niepełnosprawność”, nr 4.

Bartnikowska U. (2010b), Sytuacja społeczna i rodzinna słyszacych dzieci niestyszqcych rodziców, Wydawnictwo Edukacyjne Akapit, Torun.

Białas M. (2007), Kompetencja językowo-kulturowa a tożsamość narodowa niesłyszq̨cych, [w:] E. Woźnicka (red.), Tożsamość społeczno-kulturowa głuchych, Polski Związek Głuchych Oddział Łódzki, Łódź.

Brzezińska A. (red.) (2005), Psychologiczne portrety człowieka, Gdańskie Wydawnictwo Psychologiczne, Gdańsk.

Csányi Y. (2004), Słuchowo-werbalne wychowanie dzieci z uszkodzonym narządem stuchu, WSiP, Warszawa.

Czerniawska O. (1996), Trendy rozwojowe w zachowaniu ludzi dorostych, [w:] T. Wujek (red.), Wprowadzenie do andragogiki, Wydawnictwo i Zakład Poligrafii Instytutu Technologii Eksploatacji, Warszawa.

De Clerck G. A. M. (2012), Contributing to an era of epistemological equity: A critique and an alternative to the practice of science, [w:] P. V. Paul, D. F. Moores (eds.), Deaf Epistemologies. Multiple perspectives on the acquisition of knowledge, Gallaudet University Press, Washington.

Grzesiak I. (2003), Nazwy osobowe w polskim języku migowym, „Prace Językoznawcze", z. V.

Gunia G. (2006), Terapia logopedyczna dzieci z zaburzeniami słuchu i mowy. Wybrane problemy teorii i praktyki surdologopedy, Oficyna Wydawnicza „Impuls”, Kraków. 
Harwas-Napierała B., Trempała J. (red.) (2007), Psychologia rozwoju człowieka, Wydawnictwo Naukowe PWN, Warszawa.

Kobosko J. (2014), Edukacja głuchych. Materiały konferencyjne, RPO, Warszawa.

Korzon A. (2003), Znaczenie języka migowego we wczesnej komunikacji dzieci z zaburzeniami stuchu, [w:] E. Minczakiewicz, Dziecko niepetnosprawne. Rozwój i wychowanie, Oficyna Wydawnicza „Impuls”, Kraków.

Kossewska J. (2017), Perspektywa temporalna a zasoby osobowe głuchych/Głuchych w fazie wyłaniającej się dorosłości, [w:] E. Woźnicka (red.), Edukacja Niesłyszq̨cych - wczoraj, dziś i jutro, Wydawnictwo Akademii Humanistyczno-Ekonomicznej w Łodzi, Łódź.

Krakowiak K. (2003), Szkice o wychowaniu dzieci z uszkodzeniami słuchu, Oficyna Wydawnicza Fundacji Uniwersyteckiej w Stalowej Woli, Stalowa Wola.

Krakowiak K. (2006), Pedagogiczna typologia uszkodzeń słuchu i osób nimi dotkniętych, [w:] K. Krakowiak, A. Dziurda-Multan (red.), „Nie głos, ale słowo...”. Przekraczanie barier $w$ wychowaniu osób z uszkodzeniami słuchu, Wydawnictwo KUL, Lublin.

Oleś P. (2015), Psychologia człowieka dorosłego, Wydawnictwo Naukowe PWN, Warszawa.

Pawełczyńska A. (1984), Czas i przestrzeń a formy poznania świata, [w:] S. Nowak (red.), Wizja człowieka i społeczeństwa $w$ teoriach i badaniach naukowych, PWN, Warszawa.

Plutecka K. (2006), Kompetencje zawodowe surdopedagoga z wadq stuchu, Oficyna Wydawnicza „Impuls”, Kraków.

Podgórska-Jachnik D. (2007), Głusi wśród słyszących - głusi wśród Głuchych. Problemy integracji społecznej osób z uszkodzonym słuchem $w$ aspekcie tożsamościowym, [w:] E. Woźnicka (red.), Tożsamość społeczno-kulturowa głuchych, Polski Związek Głuchych Oddział Łódzki, Łódź.

Podgórska-Jachnik D. (2013), Głusi: emancypacje, Wydawnictwo Naukowe WSP, Łódź.

Skarżyński H., Mueller-Malesińska M., Wojnarowska W. (2002), Klasyfikacja zaburzeń słuchu, „Logopedia”, nr 28.

Szczepankowski B. (1999), Niestyszący - Głusi - Głuchoniemi. Wyrównywanie szans, WSiP, Warszawa.

Szczepankowski B. (2002), Język migowy a mowa ciała, [w:] M. Jasińska, J. Kuć (red.), Mowa ciała i jej funkcje w kulturze, Wydawnictwo Akademii Podlaskiej, Siedlce 2002.

Szczupał B. (2004), Bezrobocie osób niepetnosprawnych jako zjawisko społeczne i edukacyjne, [w:] G. Dryżałowska, H. Żuraw (red.), Integracja społeczna osób niepełnosprawnych, Wydawnictwo Akademickie „Żak”, Warszawa.

Szewczuk W. (1961), Psychologia człowieka dorosłego, Wiedza Powszechna, Warszawa.

Tomaszewski P. (2015a), Język migowy w perspektywie socjolingwistycznej, „Socjolingwistyka", nr 29(4).

Tomaszewski P. (2015b), Rozwijanie kompetencji socjokulturowej w nauczaniu polskiego języka migowego, [w:] P. Tomaszewski, K. Bargiel-Matusiewicz, E. Pisu- 
74 | Elżbieta Woźnicka

la (red.), Społeczne i kulturowe aspekty zdrowia i niepetnosprawności, Wydawnictwo Uniwersytetu Warszawskiego, Warszawa.

Tomaszewski P., Kotowska K., Krzysztofiak P. (2017), Paradygmaty tożsamości u g/Głuchych: Przegląd wybranych koncepcji, [w:] E. Woźnicka (red.), Edukacja Niestyszacych - wczoraj, dziś i jutro, Wydawnictwo Akademii Humanistyczno-Ekonomicznej w Łodzi, Łódź. 